\title{
Code-Switching in English as a Foreign Language Classroom: Teachers' Attitudes
}

\author{
Engku Haliza Engku Ibrahim ${ }^{1}$, Mohamed Ismail Ahamad $\operatorname{Shah}^{1} \&$ Najwa Tgk. Armia ${ }^{1}$ \\ ${ }^{1}$ International Islamic University Malaysia, Malaysia \\ Correspondence: Engku Haliza Engku Ibrahim, English Language Division, Centre for Languages and \\ Pre-university Academic Development, International Islamic University Malaysia, Kuala Lumpur, 53100 \\ Malaysia. E-mail: ehaliza@iium.edu.my
}

Received: April 6, 2013 Accepted: May 7, 2013 Online Published: June 3, 2013

doi:10.5539/elt.v6n7p139 URL: http://dx.doi.org/10.5539/elt.v6n7p139

The research is financed by the International Islamic University Malaysia.

\begin{abstract}
Code-switching has always been an intriguing phenomenon to sociolinguists. While the general attitude to it seems negative, people seem to code-switch quite frequently. Teachers of English as a foreign language too frequently claim that they do not like to code-switch in the language classroom for various reasons - many are of the opinion that only the target language should be used in the classroom. This study looks at the teachers' attitudes towards code-switching in teaching English as a foreign language to Malay students at one of the local universities in Malaysia. Data was collected through observations, questionnaires and interviews. Each teacher was observed, their language use were recorded, transcribed and then analyzed using the functions proposed by Gumperz (1982). The results of the study showed that teachers do code-switch in the language classroom, despite their claim that they do not. Analysis of the data showed that, in most cases, code switching by teachers was done to serve pedagogical purposes.
\end{abstract}

Keywords: code-switching, teacher's attitudes, English as a Foreign Language

\section{Introduction}

The term code itself refers to a language or a variety of a language (Wardhaugh, 1992). Ever since the 1950s, code-switching has become an interesting area of discussion in relation to bilingual or multilingual speech communities. In general, some experts agree on defining code-switching as the alternating use of two or more languages in the same utterance or conversation (Milroy and Musyken, 1995; Myers-Scotton, 1993; Faldes-vallis, 1978; Gardner-Chloros, 1997).

Milroy and Musyken (1995) stated that sometimes code-switching occurs between the turns of different speakers in the conversation, or sometimes between utterances within a single turn. It can even occur within a single utterance. In order for readers to identify the reasons or functions of switching, the approaches taken by the experts in studying code-switching are very important. In addition, utterances containing code-switching are similar to those of one linguistic variety alone in terms of discourse unity. In other words, when the switching occurs within a single sentence, the elements from the two different languages generally are joined together prosodically. The linguistic variety in code-switching may be different languages, dialects or style of the same language (Myers-Scotton, 1993).

Myers-Scotton (1993) further added that code-switching is either intersentential or intrasentential. While intersentential code-switching involves switches from one language to the other between sentences, intrasentential switching occurs within the same sentence, from single-morpheme to clause level. She then introduces the terms matrix language and embedded language. In code-switching, the matrix language is the most dominant language used and the embedded language is the language that holds the lesser role. For instance, when two native Malay speakers have a conversation in Bahasa Melayu and then they switch to English in between, Bahasa Melayu is considered as the matrix language and English is the embedded language.

Perhaps the most concrete and in depth study on code-switching was done by Gumperz (1982) where he sub-categorizes code switching into conversational code-switching and situational switching. He defines 
conversational code-switching as the juxtaposition within the same speech exchange of passages of speech belonging to two different grammatical systems or subsystems. Conversational code-switching tends to occur subconsciously as the speakers are motivated by factors within the conversation itself when it takes place. Meanwhile, situational code-switching can be considered as changes in language choice due to the situation where the speakers exist. Situational switching might take place at school, work, or public gathering where the situation demands for formality of language use.

Lin (2007) in her study, defines classroom code-switching as the alternating use of more than one linguistic code in the classroom by any of the classroom participants such as teacher and students. If we are to refer to the concept of conversational and situational switching proposed by Gumperz (1982), classroom code-switching would be considered as a form of situational code-switching. However, in the real situation within the class, conversational code-switching might take place in classroom situations. Merrit et al. (1992) argue that determining the choice of language to be used in classrooms is necessarily more complex than can be legislated by language policy on medium of instruction in classrooms (Martin-Jones, 1995).

Based on the situation mentioned above, this study looks at classroom code-switching conducted by teachers in the ESL classroom. Though the policy in English language institutions demands that English teachers use only English in teaching, the actual classroom practice might be different. Teachers might code-switch to other languages for various reasons and functions. Conversational code-switching is most likely to occur compared to situational code-switching as the choice of using other languages in teaching English may exist due to specific factors in the class. Hence, code-switching in this particular study is the alternating use of English and Bahasa Melayu within English classes by the teachers.

\section{Methodology}

This study aims to answer two research questions:

1. What are the English teachers' attitudes toward code-switching?

2. What are the functions of the teachers' code-switching within the class?

\subsection{Participants of the Study}

The participants of this study were 2 English teachers teaching at an English medium public university in Malaysia. Each teacher was observed for three 2-hour lessons. Data was collected through observations and recording of classroom discourse, interviews and questionnaires.

\subsection{Background of the Participants}

Subject A was a female English teacher aged 45. She was of Malay ethnicity and spoke Bahasa Melayu as her mother tongue. She was also a proficient English speaker with 17 years of experience in teaching English. Her highest educational background was a Masters degree. She mentioned that she also attended some additional courses on English teaching.

Subject B was a female English teacher aged 34. She was of Malay ethnicity and spoke Bahasa Melayu as her mother tongue. She was also a proficient English speaker with 13 years of experience in teaching English. Her highest educational background was a Masters degree and she had also attended Cambridge certificate in English language teaching to adults conducted by the British Council of Kuala Lumpur.

\section{Findings}

\subsection{Research Question 1: What Are the English Teachers'Attitudes toward Code-Switching?}

\section{Subject A}

Subject A code-switched 74 times. She perceived code-switching as an alternative choice in teaching English to students especially in explaining certain grammatical terms like the passive and active voice. Interestingly, subject A claimed that she only code-switched in explaining the passive and active voice, yet the observation showed that she would code-switch in explaining other grammatical structures as well. She had code-switched in teaching the passive and active voice and the perfect tenses. She also code-switched when introducing new vocabularies. When she was asked why English teachers code-switch, she mentioned three reasons for teachers to code-switch; lack of proficiency, inability to think of the proper words in English, and making the students understand better when explaining difficult terms.

Subject A claimed that she did not frequently code-switch. Code-switching for her should be the last option especially in teaching English to students whose level of English proficiency still needed to be polished. She mentioned that she would normally do her best without resorting to code-switching. Even when meeting her 
Malay students after class hours, she would not encourage her students to code-switch as she believed that students needed to be encouraged to practise their English outside the classroom environment. She would code-switch to Bahasa Melayu when there were equal comparisons to the language. If no equivalents were found, she would try her best to make the students understand using the English language.

Overall, Subject A displayed a positive attitude toward code-switching. She had code-switched for a particular reason such as in explaining difficult grammatical terms. Sometimes in explaining new terms, she would also code-switch. She believed in the use of English only in class and held the opinion that it is acceptable for English teachers to code-switch provided that the switching was seldom, as too much of switching might slow down the acquisition of the target language.

\section{Subject B}

Subject B code-switched 42 times. She admitted to rarely resorting to code-switching in the class except when most of the students were Malay. She was of the opinion that it is permissible for English teachers to code-switch if there was a need. Code-switching could be used by teachers in teaching English but the frequency should be minimized. Subject B argued that her code-switching in the classroom was culturally based. She believed that sometimes there were no right phrases or words in English to explain a concept, so code-switching to Bahasa Melayu was the only option. However, she would try not to code-switch when explaining grammatical structures. She argued that if the students wanted to learn a language, they must also understand certain technical terms of the language.

Subject B highly encouraged the use of English-only in the class. However, she inserted the particle lah quite frequently in her speech. When she was asked about this, she asserted that the insertion of the particle was meant to indicate friendliness and to show her identity as a Malaysian English speaker. She claimed that by inserting the particle, she wanted to teach her students to be aware of their own identity, that in learning English they should not sound like a European or American in speaking it, but as a Malaysian. However, she further argued that the insertion of the particle as not very good as the insertion of the particle was not globally accepted.

Subject B further argued that code-switching would not essentially impede learning the target language as the switching could be used to make the learning environment less formal. She claimed that language learning could not be conducted in a very formal way as students needed to feel comfortable in learning. Overall, Subject B indicated a positive attitude toward code-switching. She encouraged the use of English-only in the classroom, yet, code-switching was seen as necessary to create a conducive learning situation. For her, code-switching functioned for social and cultural reasons.

\subsection{Research Question 2: What Are the Functions of the Teachers' Code-Switching within the Class?}

\section{Functions of Teachers' Code-Switching}

Gumperz (1982) presents six functions of conversational functions of code-switching. Yet, the most common features of code-switching displayed by the Malaysians English speakers is the transfer of subconscious marker (Suan, 1990). Markers like lah, kan, and $t u$ are frequently used in the Malay syntactical pattern to emphasize, to seek confirmation and to enquire. Furthermore Jamaliah Moh. Ali (2000) defines the use of the marker such as lah as communicative strategies of the Malaysian English speakers. However, in addition to these, McCarthy (1991) argues that language teachers' discourse in the classroom has its own functions. Interestingly, there appeared to be another specific function of code-switching and the writer sees it as of special identity of the Muslim English speakers. Details on the functions of code-switching conducted by each teacher are presented in the next discussion.

\section{Subject A}

There were 6 functions of code-switching presented by subject A:

(1) As a message reiteration.

Gumperz (1982) states that when functioning as reiteration or repeating the message in another code, code-switching may be performed literally or in a modified form and it is serves to clarify, to emphasize, and to promote understanding. Subject A had employed 34 code-switching under this function. The examples of code-switching employed by subject A for this purpose were:

...If you say I was graduated some sort like /if I can say / $\underline{\text { saya }} \underline{\underline{\text { telah }}}$

I was

$\underline{\text { digraduasikan }}$ or saya bergraduan /you say saya bergraduan or saya

graduated I graduate I graduated I


digraduasikan...

was graduated

In the example above, code-switching to Bahasa Melayu was used to clarify the meaning of the sentence $I$ was graduated. By comparing the English words with Bahasa Melayu, the subject clarified her explanation on the passive voice. She believed that her switching to Bahasa Melayu made the students understand passive voice better as they could see the comparison. Another example of code-switching under this function was:

...so if you say he has cooked /so the meaning is that /the point is that / dia dah

$$
\text { He has }
$$

masak /he has cooked...

cooked

The example above clearly indicated that code-switching was used to make students understand the present perfect tense. As in the previous example, the teacher code-switched to Bahasa Melayu to make a comparison. In fact, during the observation, Subject A had code-switched when introducing a new grammatical structure to the students. However, when a similar topic was revised during the next session, code-switching did not occur except for the topic on the passive and active voices.

(2) As message qualification.

Subject A code-switched 28 times under this function. It is believed that when a speaker switches to the other code for this purpose, the message is better understood (Dayang Fatimah Awang Chuchu, 2007). The example of the function is:

...so, this is the passive $\underset{\text { He }}{\underline{\text { dia }}} \frac{\text { telah }}{\text { has }} \underset{\text { (been) given }}{\frac{\text { diberikan }}{\text { award }}} \frac{\underline{\text { anugerah }}}{\text { itu... }}$

In this example, the subject introduced her students to passive voice. However, in presenting the example of the concept, she switched to Bahasa Melayu because she wanted her students to understand better. Based on the interview with the subject, she admitted that she would code-switch to Bahasa Melayu especially in teaching passive voice. Another example of this function:

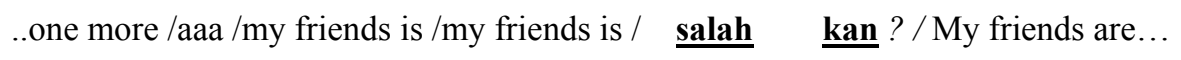

Wrong (part.)

Here, code-switching was used to qualify the previous English sentence. In this example, the subject presented an English phrase with incorrect grammatical structure. She repeated the incorrect sentences twice. However, she qualifies her point here by switching to Bahasa Melayu to justify the previous situation that the correct structure for the phrase my friends, was by using, are.

(3) As personalization versus objectivization

Code-switching here functions to describe a large class of stylistic and semantic phenomena. It reflects whether a statement is of the speaker's opinion, generally known facts, or refers to specific instances. Under this function, the exact meaning of the switching will vary depending on the context and content of the conversation (Coogan, 2003). There were 5 instances of code-switching that occurred under this function. An example for this was:

...I have eaten pun $\underset{\text { (part.) }}{\underline{\text { boleh }}} \underset{\text { can }}{\text { juga }} /$ also have eaten $\underset{\text { nasi }}{\underline{\text { nice }}} \frac{\underline{\text { lemak }}}{\text { oily }} /$ no /I have eaten

$\underline{\text { nasi lemak }}$ but in spoken actually walaupun soalan $\underline{\text { ditanya }} \quad \underline{\text { dalam }}$

rice oily

though question (was) asked

in

simple past you boleh juga jawab ya present perfect...

can also answer (part.)

The statement was the answer to a question from one of the students who was confused between the use of the simple past tense and the present perfect tense. Based on the subject's opinion, both of the sentence forms could be used to express a past situation. A switch to Bahasa Melayu was made to strengthen her opinion that even though the question was asked in the past sentence, the present perfect form can also be used as both of the tenses indicated past activity. Another example which indicated similar function is the following excerpt: 


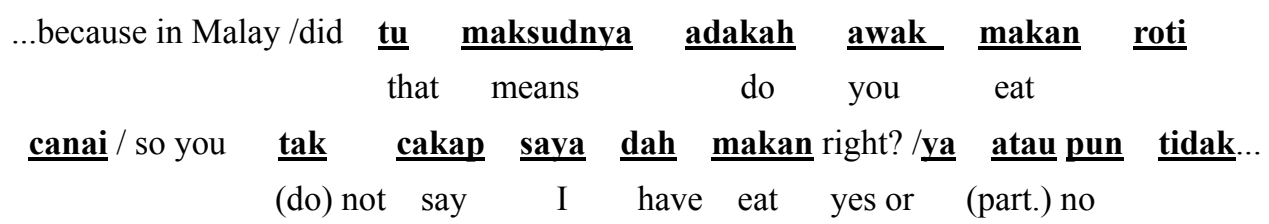

In this excerpt, she explained how to reply to the question beginning with did. She switched to Bahasa Melayu to justify her opinion that the answer to the question beginning with did was either yes or no. She wanted her students to understand the fact better so she switched to Bahasa Melayu.

\section{(4) As Interjection or sentence filler}

When functioning as Interjections or sentence filler, code-switching is used for better expression, clarification or better understanding (Gumperz, 1982). The only example for this function is:

...Not really perfect but /ok lah...

(part.)

The particle $o k$ in the above sentence was used to show a better expression. In the above example, she explained about her domestic helper as one of the students questioned it. She mentioned that her domestic helper was an old lady but she was quite reliable and hard working. She expressed her contentment for her maid by inserting the word $o k$.

\section{(5) As specific features of Islamic English}

Islamic English is the English language modified to enable it to carry Islamic proper nouns and meanings without distortion, and thus to serve the linguistic needs of Muslims users of the English language (Ismail Raji Al Faruqi, 1986). Words like Insya Allah, nazar, hikmah, and ustadz are words from the Arabic language which could not be translated into English. Those were words expressed by the subject in her teaching. There are 6 instances of code-switching recorded under this function. The examples of this are:

....and the ustadz says nothing?.

The word ustadz, which generally means religious teacher, was not translated into English by the subject as no equal word resembling the word ustadz is found in English dictionaries. There are many other examples of Islamic terms which are frequently translated into English. In this case, subject A used quite a number of Islamic terms as in the following example:

...but over a period of time $\underline{\underline{\text { Insya Allah }} . . .}$

Referring to a bilingual dictionary (Malay-English), the word Insya Allah was translated as if God wills it. Muslims usually use the word when they are expressing certain activities that are going to occur in the future. By using the phrase, Muslims are relying on Allah for every possibility. If Allah wills, then it happens. The subject seemed to be a religious person who used this phrase quite often.

(6) As the transfer of subconscious markers

The most common feature of code-switching of the Malay speaker is the transfer of subconscious markers through the insertion of particle lah (Yunisrina Qismullah Yusuf, 2006, and Suan, 1990).

\section{....Not really perfect but $/ \mathbf{o k} \underline{\mathbf{l a h}} . .$.}

(part.)

This is typical of Malaysian and Singaporean English speakers. Surprisingly, though the subject is Malaysian she rarely inserted this particle in her speech. During the interview, the subject argued that she rarely inserted the particle lah as she believed that it was not acceptable in formal English, so she minimized the use of it. Particle lah itself indicates various meanings depending on the speakers' intention (Jamaliah Moh. Ali, 2000). In this situation, the subject's usage of the particle lah had most probably happened without her realizing it. Suan (1990) argues that lah is a common particle used in Malay syntactical pattern for emphasising or seeking confirmation. Hence, when the speakers use English, they insert the particle unconsciously.

\section{Subject B}

There were 7 functions for which Subject B code-switched:

(1) As a message reiteration.

Subject B displayed 12 code-switching under this function. An example is: 
...if we want to say /this is my next step /what do you use / $\underline{\text { after }}_{\text {lepas }}^{\text {ni }} \frac{\text { his }}{\text { after }}$

ni /in English )/ ya, something like that /after this /ya...

this

In the above example, the subject employed Bahasa Melayu and then asked the students to find English translations for the words. Here, she tried to promote the students' understanding of the new words by presenting the words in Bahasa Melayu first and reiterating them in English. However, she did not directly provide the answer; she paused for a moment and even displayed a paralinguistic gesture to strengthen her point. In fact, after one of the students answered after this, she repeated the phrase after this. Another example of this function is:

...nervousness /actually good you know /it helps you to /motivate /ciee / boleh

can

/boleh / I can do /I can do...

can

The subject literally repeated the Malay words in English in order to emphasize her message. Here, she encouraged the students to have confidence in themselves when they are doing their presentations. Students should bear in mind that they can do the presentations.

(2) As message qualification

As a message qualification, code-switching functions to qualify a previously mentioned statement. It can happen at the level of sentences, clauses, and phrases level. In this situation the speaker believes that code-switching helps to better understand the message (Gumperz 1982). Based on the observation, it was discovered that subject B performed 12 code-switching under this function. One of the examples is:

...you say next $\underset{\text { baru }}{\text { then }} \quad \frac{\text { dia }}{\text { he }} \quad \frac{\text { tekan... }}{\text { press }}$

In this excerpt, the code-switching was done to qualify the previous statement. She said this to one of the students who presented his slide. She informed the presenter to say next so that the slides operator understood what to do when the presenter said next. This happened when the presentation began. She switched to Bahasa Melayu to make other students understand what to do if the instruction was given. Another example is when the subject was introducing a new vocabulary to her students. Instead of giving direct translation of the vocabulary, the subject qualified the new vocabulary by presenting a Malay idiomatic expression as in the following example:

...there was a lot of fidgeting going on during my speech /fidgeting is like / macam

$\begin{array}{lllll}\text { cacing } & \text { panas } & \frac{\text { sikit }}{\text { lah.... }} & \\ \text { like } & \text { worm } & \text { hot } & \text { a bit } & \text { (part.) }\end{array}$

The word fidgeting means the act of moving one's body restlessly. Fortunately, there is a Malay idiom to refer to this situation; macam cacing panas or literally translated as when a worm is placed under direct sunlight, it will move restlessly due to the heat.

(3) As interjection or sentence filler

Code-switching is used to indicate an interjection or sentence filler for better understanding, expression or clarification (Dayang Fatimah Awang Chuchu, 2007). Subject B displayed as many as 10 code-switching under this function. This was quite interesting as most of the switching were of typical Malaysian English expressions. As the subject mentioned during the interview, the insertion of local expression in her study was to show her identity as a speaker of Malaysian English. Moreover, most of her sentences were for the purpose of humor (McCarthy, 1991). The examples of Subject B code-switching under this function are:

$$
\text { ...try to switch off all? / } \frac{\text { alaa }}{\text { (int.) }} / \frac{\text { tak }}{\text { not }} \text { best } \quad \underline{\text { lah ... }}
$$

In this excerpt, the subject was expressing her unhappiness by using the word alaa. The word alaa or alah is an interjection used to express her feeling of being upset or being unhappy about something (Kamus Bahasa Melayu Nusantara, 2003). In this situation, the subject was unhappy about the display on the presentation screen. 
The screen was still blurred though she has adjusted to make the screen brighter. One of the students suggested that she switch off all of the lights for better display. Yet, the screen was still blurred. She used the word alaa to show that she was upset about the situation.

Additionally, subject B also code-switched to express negative feelings by inserting a typical Malay word alamak. The examples are:

....

(inter.)

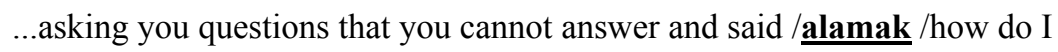

(inter.)

answered this question...

The word alamak or alah mak is an interjection used to express one's surprise which indicates disappointment (Kamus Bahasa Melayu Nusantara, 2003). In the examples above, the subject clearly indicated the she was disappointed at what was happening. The fact that she turned a student's slides to end, disappointed her, so she apologized to the student for doing so. In the second example, she explained to the students the most common situation faced by a presenter during a presentation. A presenter would be surprised if he were asked questions that he could not answer. She inserted the word alamak to express the negative feeling if she was in the situation.

\section{(4) As personalization versus objectivization}

Under this function, code-switching was used to indicate the difference between fact and opinion. Code-switching here concerns more on: the degree of speaker involvement in, or distance from, a message, whether a statement reflects personal opinion or knowledge, and whether it refers to specific instances or to a generally known fact (Gumperz, 1982). Code-switching under this function was employed 3 times. An example from the data is:

...I think mine is retarded / konon $\underline{\text { nak }}$ buat creative $\underline{\text { lah }} .$.

as if want make (part.)

She was saying something about her ability to fold a paper into an aircraft model. One of the students presented on how to make an aircraft model and all class members were asked to make their own model. When the activity was done, the subject judged her model as retarded. When one of the students asked her for the meaning of retarded she referred to Bahasa Melayu to explain her message better. She even lifted her model higher so that every student can see it. Another example is:

...he mentioned about Islamic countries which have developed well /for examples Dubai and Kuala Lumpur /ciee / aku bangga sikit lah...

$$
\text { I proud a bit (part.) }
$$

In the example, the switch to Bahasa Melayu clearly reflected her personal opinion. The subject mentioned about the speech of the president of the U.S. in Cairo. Surprisingly, in the speech, the president mentioned about some Islamic countries which had developed well, and Kuala Lumpur was mentioned as one of them. As a Malaysian, she felt proud of it and she expressed her personal opinion of the speech by switching it to Bahasa Melayu.

(5) As quotation

When functioning as quotation, code-switching contains direct quotation or reported speech (Gumperz, 1982). There were 2 code-switching occurring under this function. For instance, when the subject was recalling her previous experience, she code-switched to Bahasa Melayu in reporting the sentence. This is shown in the following excerpt

...I came like really early and went to see the cleaner / $\underline{\mathbf{k a k}}, \underline{\text { tolong }} \underline{\mathbf{k a k}} \ldots$

sister help sister

The subject was recalling her previous experience in teaching. She argued on the importance of preparation in presentation. Once, she went to observe the classroom which she would use for teaching. Unfortunately, the whiteboard in the classroom was full of writing and they were written in permanent ink. The next day she came in earlier and asked the cleaner to clean the whiteboard. The subject used reported speech to quote the sentences she used. However, she described the speech in Bahasa Melayu as she believed that the students understood her better if she used the original language of quotation. 
(6) As specific feature of Islamic English.

Suan (1990) conducted a study on code-switching among bilingual Malay students. One of her findings indicated that the subjects whose religion is Islam, inserted some Islamic terms in their utterances. Similar to subject A, subject B also inserted the word Insya Allah in her sentence to express a certain situation that is going to happen in the future. The example is:

...Insya Allah $/$ no written /just like your midterm...

In the above example, the subject was informing her students about their final exam. Just like their midterm, most probably, the questions for the final exam were like the questions for the midterm, in the form of multiple choice questions. As a Muslim, she believed that if Allah is willing the questions they would have in the final exam would be the same as the midterm questions.

(7) As the transfer of subconscious markers

Subject B displayed 8 code-switching under this function. She inserted the particle lah frequently into her discourses. During the interview, she admitted that as a Malaysian English speaker, she did the insertion for the purpose of showing friendliness. Suan (1990) argues that among Malaysians, the insertion of markers like lah, $k a h$, tu, and kan has become habitual expressions to speakers who could not avoid using it in their speech. Hence, when they speak English, it is natural for them to integrate the markers in their utterances. However, in some cases, the markers do not convey any meaning (Suan, 1990 and Jamaliah Moh. Ali, 2000). For example:

...he mentioned about Islamic countries which have developed well /for examples Dubai and Kuala Lumpur /ciee / aku bangga sikit lah...

I proud a bit (part.)

The particle lah in the example above has no specific meaning. In this example, the subject was only trying to show her emotive attitudes over her statement. In this situation, the subject felt happy that the president of the U.S. mentioned Kuala Lumpur in his speech. Therefore the word lah here was to emphasize her happiness. On the other hand, the insertion of the particle lah was also to indicate the feeling of being unhappy or upset about something as in the following example:

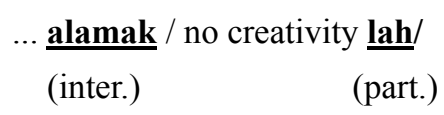

This utterance was initiated when the subject was upset about her model aircraft which was not as perfect as the others. She believed it was because she had no creativity in creating it. The example indicated that the subject was discontented with the situation she was in. It was supported with the insertion of the word alamak which indicated a negative attitude.

Overall, the occurrence of conversational functions of code-switching in both subjects is presented in the following table.

Table 1. The occurrence of conversational functions of code-switching in subject A and B

\begin{tabular}{llll}
\hline \multirow{2}{*}{ No. } & Functions of code-switching & \multicolumn{2}{l}{ Number of occurrence } \\
\cline { 3 - 4 } 1. & Message reiteration & 34 & 12 \\
2. & Message qualification & 28 & 12 \\
3. & Interjection or sentence filler & 1 & 10 \\
4. & Personalization versus objectivization & 5 & 3 \\
5. & Quotation & 0 & 2 \\
6. & Specific feature of Islamic English & 6 & 3 \\
7. & As the transfer of subconscious markers & 1 & 8 \\
& Total & $\mathbf{7 5}$ & $\mathbf{5 0}$ \\
\hline
\end{tabular}

The above table shows that subject A had code-switched 34 times mostly when repeating her message. She 
admitted in her interview that she code-switched to Bahasa Melayu to compare the passive voices. She would usually use Bahasa Melayu first and then English. On the contrary, subject B only code-switched 12 times for reiteration. Subject B claimed that she never code-switched in explaining any grammatical terms as she believed that student should be exposed to English when they want to master it.

The table shows that altogether there were seven functions of code-switching performed by both the subjects. For further information, regardless of the functions of the switching, subject A presented 74 switching during the study while subject B presented 42 switching. However, pertaining to the functions of the switching, subject A presented 75 switching and subject B presented 50 switching. This is due to the fact that some switches have multiple functions as can be seen in the examples.

\section{Discussion}

Code-switching in this particular study was the alternating use of English and Bahasa Melayu within English classes by the teachers. The subjects of this study were two English teachers of a public university in Malaysia. Both of the subjects observed in this study displayed positive attitudes towards code-switching. They believed that moderate code-switching is tolerable as long as the switches do not interfere with the essential processes of the learning itself. The use of English-only in class was highly encouraged. One of the teachers considered code-switching as an alternative way of teaching low proficiency students.

Both of the subjects stated that there were many reasons for ESL teachers to code-switch, namely, lack of proficiency, inability to find the exact words in English, promoting students' understanding particularly in explaining difficult terms, for friendliness, and to follow the usage that is found one's culture.

There were different functions of code-switching performed by each subject of the study. However, both the subjects displayed almost similar functions. Subject A had 6 functions and subject B had 7 functions. Overall, seven functions of code-switching were found in this study:

(1) Message reiteration; to reiterate or repeat a message in another code in order to clarify, emphasize, and promote understanding.

(2) Message qualification; to qualify a previously mentioned statement. In this situation the speaker believes that switching helps better understanding of the message.

(3) Interjection or sentence filler; code-switching is used for better expression, clarification or better understanding. One of the subjects of this study frequently inserted Malay interjections into her utterances.

(4) Personalization versus objectivization; code-switching was used to indicate the difference between fact and opinion. Code-switching here is concerned more with the degree of speaker's involvement in, or distance from, a message, whether a statement reflects a personal opinion or knowledge, and whether it refers to specific instances or to a generally known fact.

(5) Quotation; when functioning as quotation, code-switching contains direct quotations or reported speech.

(6) Specific feature of Islamic English; Islamic English is the English language modified to enable Islamic proper nouns and meanings to be carried out without distortion, and to serve the linguistic needs of Muslims users of the English language (Ismail Raji Al Faruqi, 1986). The subjects in this study used some Islamic terms which were not translated because some of the terms have no equivalent in English.

\section{Conclusion}

The findings of this study are mostly in accordance with the theory proposed by Gumperz (1982) on conversational functions of code-switching. However, there are two important findings to be highlighted here as they are different from the findings of other studies on code-switching. First, with reference to Malaysian English, the insertion of particles such as lah is a specific feature of Malaysian English. Jamaliah Mohd. Ali (2000) argued that the particle communicates no particular denotative meaning yet, it is used to indicate emotive and affective attitudes of the speaker, or sometimes simply to fill a pause or a moment of hesitation or reflection in the stream of speech. It is categorized as part of the communication strategies of Malaysians in speaking English. One of the subjects of this study only inserted one lah particle in her discourse while another subject inserted quite a number of lah particles together with other particles such as kan, tu, and kah. The insertion of these particles was categorised as the transfer of subconscious markers. This has become habitual expressions to Malaysians who could not avoid using it in their speech. Hence, when they speak English, it is natural for them to integrate the word into their utterances (Suan, 1990).

Second, with reference to Islamic English, both of the subjects inserted some Islamic terms into their spoken discourse. The word Insya Allah was used commonly by the subjects. In a bilingual dictionary (Malay-English), 
the word Insya Allah is translated as if God wills it. Muslims usually use the word when they are expressing certain activities that are going to occur in the future. By using the phrase, Muslims are relying on Allah for every possibility. If Allah wills, then it happens. As Suan (1990) has discovered most Malay English speakers who are Muslims, will insert some Islamic terms in their utterances.

The results of the interviews and the observations corroborated with the results from the questionnaire. Overall, other respondents of the questionnaires displayed positive attitudes toward code-switching, though they explicitly disapproved the practice of code-switching in their ESL classrooms.

\section{References}

Asmah Haji Omar. (1992). The linguistics scenery in Malaysia. Kuala Lumpur: Dewan Bahasa dan Pustaka Kementrian Pelajaran Malaysia.

Auerbach, E. R. (1993). Reexamining English only in the ESL classroom. TESOL Quarterly, 27(1), 9-32. http://dx.doi.org/10.2307/3586949

Auer, P. (2001). Code-switching: discourse models. In Mesthrie, R. (Ed.), Concise encyclopedia of sociolinguistics (pp. 443-446). Oxford: Elsevier.

Awang Sudjai Hairul and Yusoff Khan. (Ed.). (1977). Kamus lengkap. Selangor: Pustaka Zaman Sdn Bhd.

Badrieh Ahmed Dehrab. (2002). A study of code-switching in four English for specific purposes classrooms at the college of business studies in Kuwait. Doctoral dissertation international (UMI Number: 3049013).

Badrul Hisham Ahmad and Kamaruzzaman Jusof. (2009). Teachers' code-switching in classroom instructions for low English proficient learners. Retrieved $26^{\text {th }}$ of April, 2009, from www.ccsenet.org/journal.html

Bethuysen, R. V. (2005). Code-switching: Instructor use of L1 in ESL classroom. Retrieved March 3, 2009, from http://cicero.u-bunkyo.ac.jp/lib/kiyo/fsell2006/EIBUN095_105.pdf

Boztepe, E. (n.d.). Issues in code-switching: Competing theories and models. Retrieved March 3, 2009, from http://journals.tc-library.org/ojs/index.php/tesol/article/viewFile/32/37

Cheng, K. K. Y. (2003). Code-switching for a purpose: Focus on pre-school Malaysian children. Multilingua journal of cross-cultural and interlanguage communication, 22(1), 59-77. http://dx.doi.org/10.1515/mult.2003.004

Coogan, R. T. (2003). Code-switching and classroom type. Master thesis. Proquest online thesis and dissertation.

Corbetta, P. (2003). Social research, theory, methods and techniques. London: Sage publication.

Crismore, A., et.al. (1996). Attitudes toward English in Malaysia. World Englishes, 15(3), 319-335. http://dx.doi.org/10.1111/j.1467-971X.1996.tb00118.x

Crystal, D. (1997). English as a global language. Cambridge: Cambridge University Press.

Cui, Yanping. (2006). Code-switching by Chinese English-as-a-second-language students in computer-mediated communication: a multiple case study. Master thesis. Proquest online thesis and dissertation.

Crystal, D. (1987). The Cambridge encyclopedia of language.

David, M. K. (2003). Preface. Multilingua - journal of cross-cultural and interlanguage communication, 22(1), 1-4. http://dx.doi.org/10.1515/mult.2003.001

David, M. K., \& Govindasamy, S. (2003). Language education and 'nation building' in multilingual Malaysia. In Bourne, J., \& Reid, E. (Eds.), Language education (pp. 215-225). UK: Kogan page.

David, M. K. (2004). Language policies in a multilingual nation: Focus on Malaysia. Teaching of English in second and foreign language settings. Frankfurt: Peter Lang.

Deckrow, Elsa R. (2005). Code-switching in a second grade bilingual classroom: A teacher research study. Doctoral dissertation international (UMI Number: 3207253).

Dayang Fatimah Awang Chuchu. (2007). Code-switching in a multilingual environment. Perak: Penerbit university pendidikan Sultan Idris Tanjong Malim.

Gardner-Chloros, P. (1997). Code-switching: language selection in three Strasbourg Department stores. In Coupland, N., \& Jaworski, A. (Eds.), Sociolinguistics a reader and coursebook (pp. 361-375). London: MacMillan press Ltd.

Govindasamy, S. (2009). Personal communication. Gombak, Selangor, $29^{\text {th }}$ of May, 2009. 
Gumperz, J. J. (1982). Discourse strategies. Cambridge: Cambridge University Press. http://dx.doi.org/10.1017/CBO9780511611834

Ismail Raji Al-Faruqi. (1986). Toward Islamic English. USA: International institute for Islamic thought.

Jamaliah Mohd. Ali. (2000). Verbal communication: A study of Malaysian speakers. Kuala Lumpur: University of Malaya Press.

Kasperczyk, L. (2005). Implementing Code-Switching in the Classroom. Unpublished undergraduate thesis. Daemen College, Amherst, New York. Retrieved September 1, 2008, from http://www.daemen.edu/academics/SRT/articles_files/DURF_Kasperczyk_2005_Paper.pdf

Kaur, S. (2007). Code switching by teachers in the English language classroom. Master practicum report. University Kebangsaan Malaysia.

Knowles, G. (2004). English 2020: The future of English in Malaysia. Language, linguistics and the real world, (Vol. 1), pp. 23-49. Kuala Lumpur: University of Malaya Press.

Lin, A. M. Y. (2007). Code-switching in the classroom: Research paradigms and approaches. Encyclopedia of language and education (pp. 3464-3477). Retrieved March 3, 2009 from http://springerlink.metapress.com/content

Lowenberg, P. H. (1986). Sociolinguistics context and second language acquisition: acculturation and creativity in Malaysian English. World Englishes, 5(1), 71-83. http://dx.doi.org/10.1111/j.1467-971X.1986.tb00641.x

Lucas, T., \& Katz, A. (1994). Reframing the Debate: the roles of native languages in English-only programs for language minority students. TESOL Quarterly, 28(3), 537-561. http://dx.doi.org/10.2307/3587307

MacCarthy, M. (1991). Discourse analysis for language teachers. Cambridge: Cambridge university press.

Martin-Jones, M. (1995). Code-switching in the classroom: two decades of research. In Milroy, L., \& Musyken, P. (Eds.), One speaker, two languages; cross disciplinary perspectives on code-switching (pp. 90-111). Cambridge: Cambridge University Press. http://dx.doi.org/10.1017/CBO9780511620867.005

McCormick, K. M. (2001). Code-switching: overview. In Mesthrie, R. (Ed.), Concise encyclopedia of sociolinguistics (pp. 447-453). Oxford: Elsevier.

Milroy, L., \& Musyken, P. (1995). Introduction: code-switching and bilingualism research. In Milroy, L., \& Musyken, P. (Eds.), One speaker, two languages; cross disciplinary perspectives on code-switching (pp. 1-14). Cambridge: Cambridge University Press. http://dx.doi.org/10.1017/CBO9780511620867.001

Moore, D. (2002). Case Study Code-switching and Learning in the Classroom. International Journal of Bilingual Education and Bilingualism, 5(5), 279-293. http://dx.doi.org/10.1080/13670050208667762

Musyken, P. (1995). Code-switching and grammatical theory. In Milroy, L., \& Musyken, P. (Eds.), One speaker, two languages; cross disciplinary perspectives on code-switching (pp. 177-198). Cambridge: Cambridge University Press. http://dx.doi.org/10.1017/CBO9780511620867.009

Muthusamy, P. (2009). Communicative functions and reasons for code-switching: A Malaysian perspective. Retrieved $28^{\text {th }}$ of July, 2009, from http://www.crisaps.org/newsletter/summer2009/Muthusamy.doc

Myers-Scotton, C. (1995). A lexically based model of code-switching. In Milroy, L., \& Musyken, P. (Eds.), One speaker, two languages; cross disciplinary perspectives on code-switching (pp. 233-256). Cambridge: Cambridge University Press. http://dx.doi.org/10.1017/CBO9780511620867.011

Najwa Tgk. Armia. (2009). Code-Switching Among ESL Teachers: A Case Study of IfLA at the International Islamic University Malaysia. Unpublished MA thesis.

Ou, C., \& Zheng, J. (2008). Research on the code-switching based on the data collected from students in Nankai University. US-China Foreign Language, 6(1) (Serial No. 52).

Poplack, S. (2000). Sometimes I'll start a sentence in Spanish/ y termino en Español/: toward a typology of code-switching. In Li Wei (Ed.), The bilingualism reader (pp. 221-256). London: Routledge.

Rumaiza Abdul Rahman. (2009). Writer's interview. Gombak. Selangor. $21^{\text {st }}$ of August 2009.

Sert, O. (2005). The functions of code-switching in ELT classrooms. The Internet TESL Journal, 11(8), Retrieved $26^{\text {th }}$ of April, 2009, from http://iteslj.org/

Suan, Ong Kin. (1990). A study of code-switching among bilingual Malay students in certain urban secondary schools. Unpublished master thesis. University of Malaya: Kuala Lumpur. 
Valdès-Fallis, G. (1978). Code switching and the classroom teacher. Language in education: theory and practice (pp. 5-31). Virginia: Center for Applied Linguistics.

Wardhaugh, R. (1992). An introduction to sociolinguistics (2 ${ }^{\text {nd }}$ ed.). London: Blackwell.

Yunisrina Qismullah Yusuf. (2006). A pragmatics analysis of a teacher's code-switching in a bilingual classroom. Unpublished research paper. University of Malaya: Kuala Lumpur.

Zabrodskaja, A. (2007). Russian-Estonian Code-Switching in the University. Arizona Working Papers in SLA \& Teaching, 14, 123-139.

Zaidan Ali Jassem. (1994). Malaysian English: A sociolinguistic and TESL/TEFL perspective. Kuala Lumpur: Pustaka antara.

\section{Copyrights}

Copyright for this article is retained by the author(s), with first publication rights granted to the journal.

This is an open-access article distributed under the terms and conditions of the Creative Commons Attribution license (http://creativecommons.org/licenses/by/3.0/). 